\title{
Soil Water Movement of a Mangrove Forest in Halmahera Island, East Indonesia
}

\author{
Takeshi TOMA United Graduate School of Agricultural Sciences, Ehime University, Matsuyama \\ 790, Japan. Present address: Forest Environment Division, Forest and Forest Products \\ Research Institute, P.O. Box 16, Tsukuba Norin Kenkyu Danchi, Ibaraki 305, Japan \\ Kazuhiko OGINO College of Agriculture, Ehime University, Matsuyama 790, Japan
}

\begin{abstract}
Soil water movement, salinity and redox potential of soil water and soil $\mathrm{pH}$ were studied in a well developed mangrove forest in Halmahera Is., East Indonesia. The study area was classified into four zones of dominant species, the Sonneratia alba (S), Hibiscus tiliaceus $(\mathrm{H})$, the mixed stand of Rhizophora apiculata and Bruguiera gymnorrhiza (Ra-B), and Rhizophora stylosa, Nypa fruticans and Xylocarpus granatum (Rs-N) zones. The $\mathrm{S}$ zone was inundated by neap high tide. The Ra-B and Rs-N zones were inundated only the occasion of spring high tide. The $\mathrm{H}$ zone was not inundated. The soil water table was raised to ground surface when flooded. The level of water table was kept close to ground surface on the day of flood, but it was lowered down during the period of no flood. At the end of the period of no flood, the soil water level in the Rs-N zone was lowered to $70 \mathrm{~cm}$ below ground surface, while that in the Ra-B zone to $30 \mathrm{~cm}$. Highly reductive condition appeared at $20 \mathrm{~cm}$ depth in the $\mathrm{S}$ and Ra-B zones. In the Rs-N zone, the condition was oxidative to slightly reductive even at $70 \mathrm{~cm}$ depth to some extent. When the soil was desiccated, acidity of the soil increased in the reductive soil of $\mathrm{S}$ and Ra$\mathrm{B}$ zones. In the Rs-N zone, high acidity was observed only in deeper layer.
\end{abstract}

Key Words : mangrove forest / redox potential / soil drainage / soil pH / soil water table / tidal inundation.

Mangrove forests develop on the tropical coastal areas which are inundated by tidal water. Soil salinity in relation to distribution of dominant mangrove tree species has been well studied in situ. The salinity in relation to inundation frequency has well been discussed (Clarke \& Hannon, 1969; Chapman, 1976; Watson, 1928; etc.).

Oxygen diffusion through the water is extremely slow. Once the soil pores are filled with stagnant water, the oxygen supply to the deeper soil is practically shut off. The oxygen consumed in the deep soil by various bio-chemical processes, e.g. organic matter decomposition, root and microorganism respiration etc., are not able to be fully supplied. Consequently soil condition becomes anaerobic (Russell, 1973).

Water stagnation or anaerobic condition is deemed to be an important factor to determine dominant species. Some species show the preference of the well drained site (Macnae, 1968) where the oxygen concentration in soil is relatively high(Chapman, 1976). The redox potential, index for soil oxidation reduction status or aeration condition, of soil has been used to explain species distribution (Diemont \& Wijingaarden, 1975; Spenceley, 1982). The redox potentials of mangrove sediments vary from site to site depending upon the frequency and duration of inundation, drainage, organic matter content, and the availability of electron acceptors (Clough et al, 1983). 


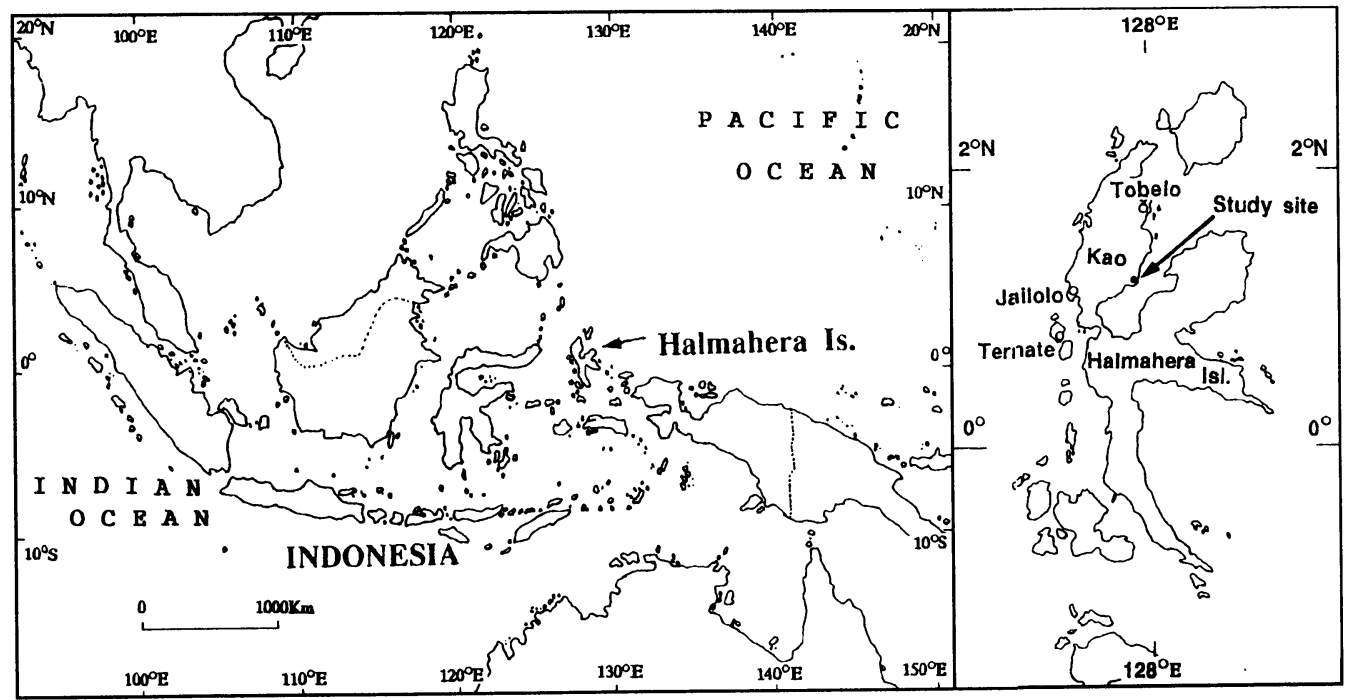

Fig. 1. Location of study site

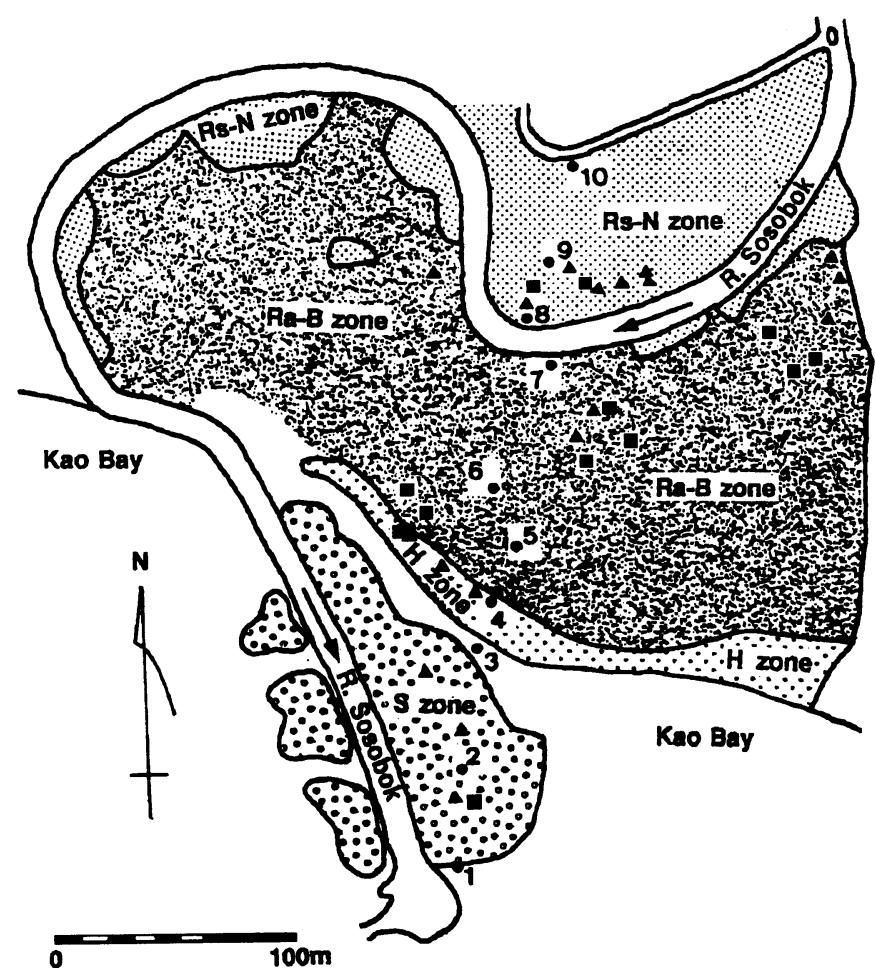

Fig. 2. Map of vegetation of study site and location of measuring points (redrawn from Komiyama et al., 1988a). Dots: the level of water table and the quality of soil solution were studied. Squares: the quality of soil solution were studied. Triangles: the soil samples were collected.

The oxidation-reduction status of the soils closely relate to the chemical process of the soils. In coastal soils, sulphate ions of sea water under highly reductive condition are reduced to sulfides to form pyrites which accumulate. Once the condition turns to oxidative, the accumulated sulfides are oxidized to sulfuric acid to turn the soils highly acidic. This phenomenon is well known as the formation of acid sulfate soil (Kyuma, 1986). The studies for acid sulfate soil of mangrove area used to focus on agricultural land use.

The soil water conditions are important factors determining the chemical condition of mangrove soils. Chapman (1976) pointed out that the knowledge of the soil water movement 
had been very poor. Nevertheless, the studies on water movement and oxidation reduction status of mangrove soils are still very few.

The present study aims to clarify the effect of soil water movement on mangrove soil characteristic in Halmahera Is., East Indonesia. The frequency and duration of inundation were determined by analyzing the tide level measurement and microrelief survey. The level of water table were also observed. The salinity and redox potential of soil water and $\mathrm{pH}$ of fresh soil were determined in situ. The $\mathrm{pH}$ of aerial dried soil were also examined.

\section{STUDY SITE}

A mangrove forest along the coast of Kao Bay of Halmahera Island $\left(1^{\circ} 10^{\prime} \mathrm{N}, 127^{\circ} 57^{\prime} \mathrm{E}\right)$ was selected for the study site (Fig. 1). It was moderately stretched mangrove forest developed on the mouth of the Sosobok, a meandering small river, flows into the Kao Bay (Fig. 2).

No meteorological records were available at Kao. Data on rain fall in the adjacent area were available at Tobero and Jailolo on Halmahera Is., and Ternate on Ternate Is. Data from all the stations recorded more than $2,000 \mathrm{~mm}$ precipitation per annum and which was distributed over $100 \mathrm{~mm}$ a month throughout a year(Boerema, 1925).

An area of 8.4 ha was marked on the site. The vegetation was surveyed as given in Fig. 2. Floristic composition and stand structure of the study site were reported by Komiyama $e t$ al.(1988a). The zonal structure of the vegetation was clearly defined by dominant species. Both side of the river mouth were occupied by Sonneratia alba (S zone). On the inland side of $\mathrm{S}$ zone, there found a narrow sand dune dominated by Hibiscus tiliaceus ( $\mathrm{H}$ zone). On the back of the sand dune a mud flat spread. The mud flat seemed to be developed by the sedimentation of meandering river. The dominant species were the mixed stand of Rhizophora apiculata and Bruguiera gymnorrhiza with occasional pure stand of $B$. gymnorrhiza (Ra-B zone). Another side of meander was dominated by the mixture of Nypa fruticans, Rhizophora stylosa and Xylocarpus granatum (Rs-N zone).

The forest was well developed and fairly well reserved. The largest tree was observed in the Ra-B zone. The canopy layer of the Ra-B zone reached to over than $30 \mathrm{~m}$ in height. The largest diameter at breast height of the tree trunk was measured at $85.6 \mathrm{~cm}$ for a $B$. gymnorrhiza tree and the tallest height was estimated at $41.7 \mathrm{~m}$ for a $R$. apiculata tree by allometric relationship. Stand densities of the Ra-B zone were calculated at 300 to 761 trees/ha for trees larger than $8 \mathrm{~cm}$ in trunk diameter. The above ground biomass of Ra-B zone were estimated at $299 \mathrm{t} / \mathrm{ha}$ to $437 \mathrm{t} / \mathrm{ha}$ (Komiyama et al., 1988a, 1988b).

\section{METHOD}

Ten plastic pipes, $3.6 \mathrm{~cm}$ in inner diameter and $2 \mathrm{~m}$ long, with holes at their lower part $(80$ $\mathrm{cm}$ ) were perpendicularly driven into the ground to $1 \mathrm{~m}$ depth. The holes were distributed on the pipe from 20 to $100 \mathrm{~cm}$ below ground surface as seen in Fig. 3. The water levels in pipes were repetitively monitored.

Ten pipes were arranged to a line about $300 \mathrm{~m}$ inland from seashore at certain interval of distance (Fig. 2). The water level were measured three times a day. At about $9.00 \mathrm{~h}, 12.00 \mathrm{~h}$ and $16.00 \mathrm{~h}$, from September 4 to $25,1986$. 


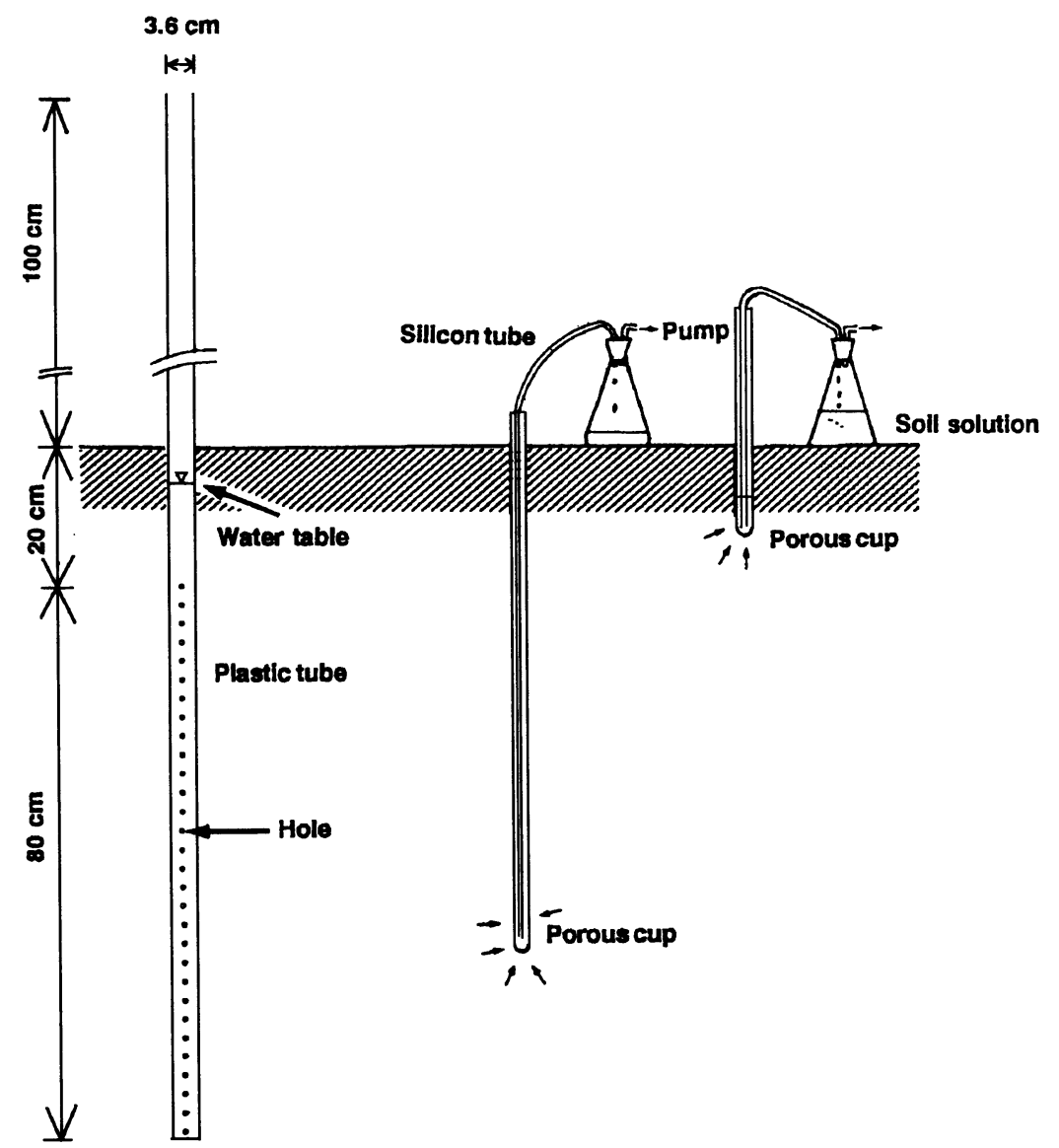

Fig. 3. The water table gauge (left). A plastic pipe of $3.6 \mathrm{~cm}$ inner diameter, perforated as to $100 \mathrm{~cm}$ below ground level. Apparatus for soil solution collection (right).

Micro-relief was surveyed during $9.18 \mathrm{~h}$ and $10.15 \mathrm{~h}$ on September 6, 1986 when all pipes except one on the sand dune were submerged with the spring high tide. The water depth of any pair of the measuring pipes were measured simultaneously to determine the deference of ground level of the two. The elevation of sand dune was measured from the nearest point by means of level survey.

Soil water was extracted and collected at 17 points (Fig. 2). At each point soil water was taken from either 10 and $70 \mathrm{~cm}$ or 20 to $50 \mathrm{~cm}$ depth. An unglazed cup connected to silicone tube was inserted into ground and soil water was sucked by hand operated vacuum pump (Fig. 3). The redox potential (Eh) and salinity of the soil water were determined immediately after sampling with a portable oxidation-reduction potential meter (TOA RM-1K) and a salinity refractometer, respectively. Sea water collected from Kao Bay and river water collected at pipe No. 7 (Fig. 2) at low tide were measured as well.

Soil pits were dug out at each zones (Fig. 2). Fresh soils were sampled to measure $\mathrm{pH}$. Taken $30 \mathrm{~g}$ of fresh soil were suspended with $50 \mathrm{ml}$ of distilled water. After half an hour later the $\mathrm{pH}$ was measured by a portable $\mathrm{pH}$ meter (TOA WQC-2A). The soil samples were aerial dried and sieved to $2 \mathrm{~mm}$ mesh size. The $\mathrm{pH}$ of aerial dried soil were measured for each soils. Taken $10 \mathrm{~g}$ of aerial dried soil were suspended with $25 \mathrm{ml}$ of distilled water. After half an hour later the $\mathrm{pH}$ was measured by a $\mathrm{pH}$ meter (TOA HM-208). The soil texture were 
determined by the pipet-method.

\section{RESULTS}

\section{Inundation frequency, duration and depth in relation to microrelief}

The results of microrelief survey and water level measurements were summarized in Table 1 . The relative elevations give the difference of elevation of each point from point No. 1. The vegetation profile and microrelief along the measuring line were illustrated in Fig. 4. From point No. 1, seaward fringe of the $S$ zone, ground level increased abruptly to about $70 \mathrm{~cm}$ and it became flat until the sand dune. Sand dune ( $\mathrm{H}$ zone), at point No. 4 , was the highest of the

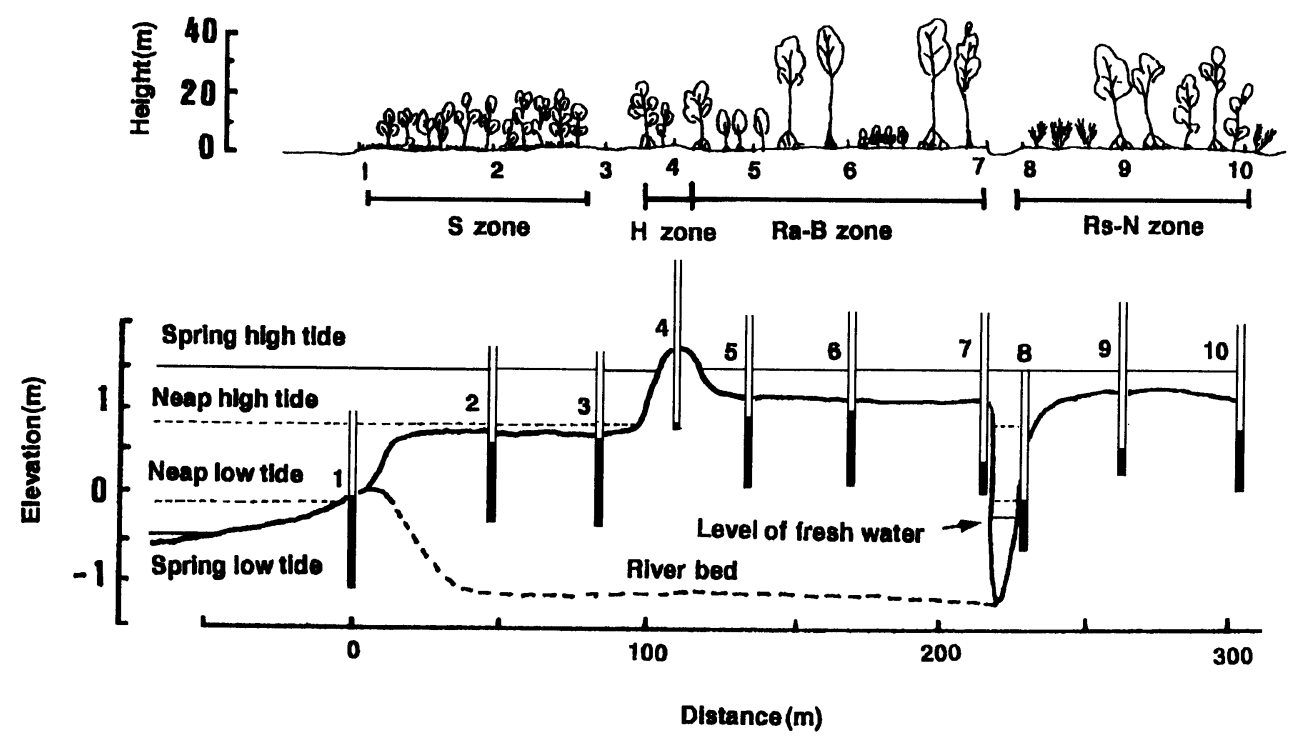

Fig. 4. Top: profile of vegetation zones. Bottom: Tide level and the lowest level of water table reached at each point, recorded during between September 4 and $25,1986$.

Table 1. The summarized results of microrelief, inundation survey and water level measurements.

\begin{tabular}{|c|c|c|c|c|c|c|c|c|c|c|}
\hline$\overline{\text { Point }}$ & Relative & Inur & idation* & & & Tide le & $\mathrm{vel}^{* *}$ & & Water leve & bserved \\
\hline No. & $\begin{array}{c}\text { Elevation } \\
(\mathrm{cm})\end{array}$ & $\begin{array}{l}\text { frequency } \\
\text { (1/14 days) }\end{array}$ & $\begin{array}{l}\text { duration } \\
(\mathrm{hr} / 336 \mathrm{hr})\end{array}$ & $\begin{array}{l}\mathrm{SH} \\
(\mathrm{cm})\end{array}$ & $\begin{array}{l}\mathrm{NH} \\
(\mathrm{cm})\end{array}$ & $\begin{array}{l}\text { SL } \\
(\mathrm{cm})\end{array}$ & $\begin{array}{l}\text { NLL } \\
(\mathrm{cm})\end{array}$ & $\begin{array}{r}\mathrm{NHL} \\
(\mathrm{cm})\end{array}$ & $\begin{array}{l}\text { highest } \\
(\mathrm{cm})\end{array}$ & $\begin{array}{l}\text { lowest } \\
(\mathrm{cm})\end{array}$ \\
\hline 1 & 0 & 18 & 303 & 153 & 91 & -42 & -3 & 86 & 130 & -1 \\
\hline 2 & 71 & 26 & 162 & 82 & 21 & -113 & -74 & 15 & 75 & -16 \\
\hline 3 & 67 & 25 & 176 & 86 & 24 & -109 & -70 & 19 & 100 & 0 \\
\hline 4 & 179 & 0 & 0 & -26 & -88 & -221 & -182 & -93 & -38 & -93 \\
\hline 5 & 119 & 19 & 37 & 34 & -28 & -161 & -122 & -33 & 30 & -29 \\
\hline 6 & 116 & 21 & 41 & 36 & -25 & -158 & -119 & -30 & 29 & -19 \\
\hline 7 & 109 & 22 & 57 & 44 & -18 & -151 & -112 & -23 & 37 & -74 \\
\hline 8 & 30 & 21 & 245 & 123 & 61 & -72 & -33 & 56 & 109 & -24 \\
\hline 9 & 121 & 19 & 32 & 32 & -30 & -163 & -124 & -35 & 18 & -74 \\
\hline 10 & 107 & 23 & 59 & 46 & -16 & -149 & -110 & -21 & 30 & -34 \\
\hline
\end{tabular}

*: For a period of successive two spring tide (September 5 - 18,1986).

: From ground surface of each point. SH: spring high tide. NH: neap high tide. SL: spring low tide

NLL: neap lower low tide. NHL: neap higher low tide. 

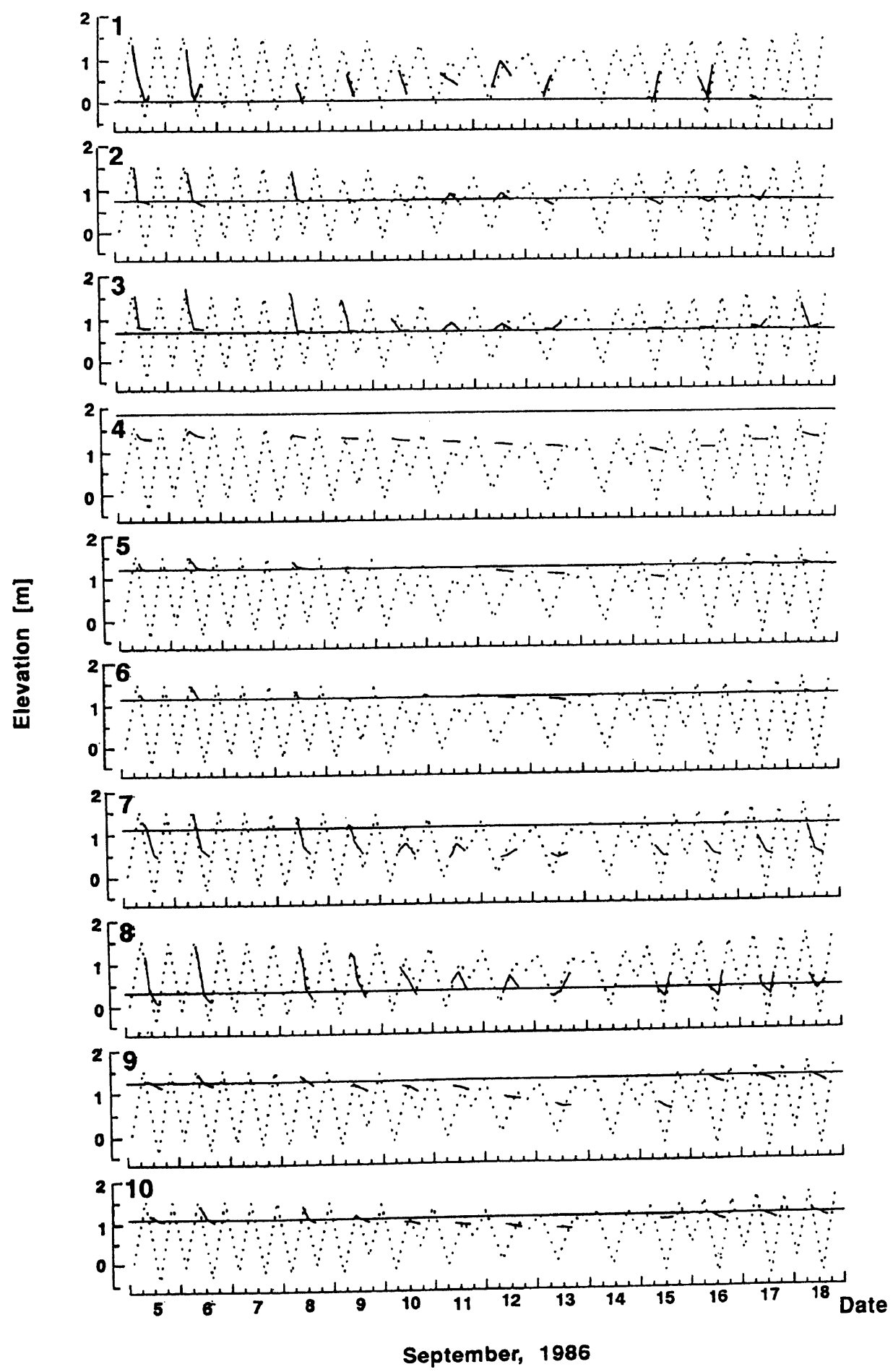

Fig. 5. Fluctuation of the level of water table at each point throughout one tidal cycle. Numerals represent measuring points. Thick solid line: Observed level of water table. Dotted line: Tidal level according to 1986 Tide Tables vol. 2. (Maritime safety agency Japan, 1985). Horizontal line represent the level of ground surface at each point. 
measuring points. Inland side of the sand dune (Ra-B zone and Rs-N zone), was kept more or less even except the river banks. The shapes of river banks were different from each other. At the outer corner, the point No. 7, the bank was subject to severe erosion by stream. The profile showed steep almost vertical slope down into the river. At the inner corner, the point No. 8, was on the silting bank where the ground surface raised gently.

At the spring high tide, the S, Ra-B and Rs-N zones were flooded. As tidal level did not exceed sand dune ( $\mathrm{H}$ zone), the top of the sand dune was never inundated. The tidal water flowed upward through the Sosobok river. The back side of the sand dune (Ra-B and Rs-N zone) was flooded from inland. At the neap hightide, the $\mathrm{S}$ zone was flooded. Although, the tidal water flowed upward through Sosobok river the Ra-B, Rs-N and $\mathrm{H}$ zones were not flooded.

Fig. 5 shows the expected change of water level at each measuring point as given by the tidal chart (Maritime Safety Agency Japan, 1985) for the period of the measurement. The surface water movement, inundation frequency, inundation duration and depth of water level were determined by using Fig. 5. The inundation frequency was given as the counts of the occurrence of the tidal level exceeding the soil surface. Inundation duration was determined by summing the periods when the tidal level was higher than soil surface. The depth of flooding water was calculated from the differences between the tidal level and soil surface.

The inundation frequency in Table 1 was determined by the tidal range and relative elevation. The lowest inundation frequency was observed at the site where the ground level was higher than the level of spring high tide (H zone, point No. 4). The inundation frequency of this site was zero because it was never flooded by any tide. For the site where the ground level was lower than spring low tide, the inundation frequency was also the lowest, zero, because it was continuously flooded.

When the ground surface was between the level of lower high tide and higher low tide of the neap, the site was inundated at every high tide and exposed at every low tide resulted in the highest inundation frequency. If the ground surface increased from that level (point Nos. 5, 6, 7, 9,10 ), inundation frequency became lower because the frequency of the flooding high tide decreased. On the contrary, if the ground surface decreased (point Nos. 2, 3, 8, 1), the frequency of low tide higher than the ground surface increased. When such low tide occurred, the inundation continued two successive high tides and this resulted in a lower inundation frequency.

The inundation duration was related to ground level. The higher the ground level the shorter the inundation duration became (Table 1). The period of each inundation was also decreased with the increasing ground elevation. In the Ra-B and Rs-N zones, the period of each inundation were less than three hours. In these zones, inundation did not occur for successive several days during the neap tide. In the $S$ zone, each inundation lasted approximately six hours. On September 13 to 14, the neap higher low tide exceeded the ground level of the $S$ zone at point No. 2 and the inundation continued for 15 hours (Fig. 5).

The surface water level estimated from the tidal chart (Maritime Safety Agency Japan, 1985) were corresponded to the observed values during high tide (Fig. 5). In the Ra-B and Rs-N zones the depth of flooding water reached to about $30 \mathrm{~cm}$ and in the $\mathrm{S}$ zone it exceeded $1 \mathrm{~m}$ at the spring high tide.

\section{Soil water movement}

The soil water level rose to the ground surface when inundated. The rise of soil water level 
Table 2. Soil texture of each vegetation zone.

\begin{tabular}{lclcc}
\hline & Depth [cm] & sand[\%] & silt [\%] & clay [\%] \\
\hline S zone & $0-5$ & 86.0 & 4.6 & 9.4 \\
& $40-45$ & 69.2 & 10.9 & 20.0 \\
\multirow{4}{*}{ H zone } & $80-95$ & 55.6 & 20.8 & 23.7 \\
& $0-5$ & 97.2 & 1.1 & 1.7 \\
& $40-45$ & 96.7 & 1.1 & 2.2 \\
Ra-B zone & $80-85$ & 89.5 & 3.0 & 7.5 \\
& $0-5$ & 68.1 & 10.1 & 21.7 \\
& $40-45$ & 66.1 & 10.4 & 23.5 \\
Rs-N zone & $00-85$ & 57.8 & 16.1 & 26.0 \\
& $0-5$ & 24.8 & 29.9 & 45.3 \\
& $40-45$ & 25.9 & 28.5 & 45.6 \\
& $80-85$ & 32.7 & 28.0 & 39.3 \\
\hline
\end{tabular}

without inundation were observed only at point Nos. 4 and 7. The soil water level of the others did not rose without inundation, even when the tide level was higher than the soil water level (Fig. 5).

The soil water level were lowered gradually, when the surface soils were uncovered. The rate of soil water movement was so slow that the level did not follow the daily tidal movement. In the S zone (No. 2) and Rs-N zone (Nos. 9 and 10), the rate of soil water movement was relatively higher than observed in the Ra-B zone (Nos. 5 and 6). Although, the rate of the Rs-N zone was larger than that of the Ra-B zone, the soil texture was more clayey in the Rs-N zone (Table 2). It seemed that the soil water mobility was not solely determined by the soil texture. The larger soil water mobility in the Rs-N and $\mathrm{S}$ zone could be attributable to the tunnel like water way developed in the soil.

The longer the period of non-inundation, the deeper the soil water level became. After several days of non-inundation, the water level of Rs-N zone (No. 9) fell down until $74 \mathrm{~cm}$ below ground surface. In the Ra-B zone (No. 6), the soil water level was $19 \mathrm{~cm}$ depth.

At the river bank (No. 7), the soil water level followed the movement of water level of the Sosobok. At the point $20 \mathrm{~m}$ apart from the Sosobok the soil water level did not follow the water level of the Sosobok. It seemed the lateral permeation from the river caused the soil water level in the vicinity of the river. The soil water level in the $\mathrm{H}$ zone (No. 4) raised only during the spring high tide. When spring low tide, inland side of sand dune was not flooded, the water level of No. 4 decreased rapidly and kept to the same level of No. 5. It was deemed the water table of No. 4 was sustained by lateral permeation.

From the results mentioned above we concluded that the soil water mobility were so small that the soil water level did not follow the daily tidal movement. It showed the longer ranged tendency to follow the water level of spring-neap tidal cycle. The soil water mobility was not solely determined by water permeability of soil body, but it was attributable to the development of underground water way in the soil. From the fact that the soil water moves so slow, water supply to the soils could only be expected from the flood covering the ground.

\section{Salinity of soil water}

The vertical distribution of the salinity of soil water in the S, Ra-B, and Rs-N zones are respectively given in Fig. 6 . The soil water salinity revealed steadily constant at ca. $35 \%$ in the $\mathrm{S}$ zone, fluctuated between 30 to $40 \%$ in the Ra-B and Rs-N zones. It was disclosed that 


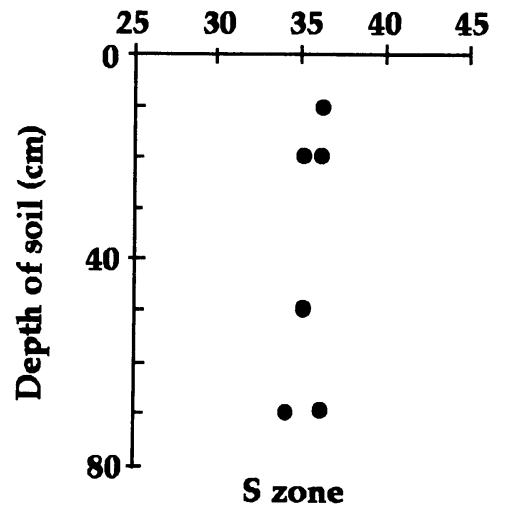

S zone
Salinity (\%)

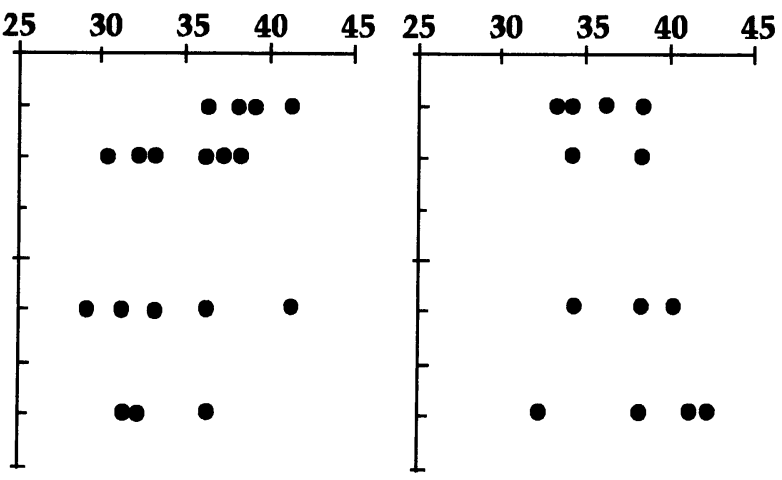

Ra-B zone

Rs-N zone

Fig. 6. Vertical distribution of salinity in soil solution.

those values of soil water salinity were almost equivalent to that of sea water.

The salinity of river water taken at the point near No. 7 at the spring low tide, however, was measured at ca. $5 \%$. It was raised to 30 to $35 \%$ nearly equal to the salinity level of sea water at the high tide. At the spring low tide the water table of the Sosobok became the lowest. It was slightly higher than sea level at the point near No. 7 (Fig. 4) and gently flowing down stream. Comparing the fresh water level with soil water of the surroundings, it was confirmed that the fresh water level was far lower than the lowest soil water level. Therefore, the fresh water never covered the soil surface.

The river water flowed upstream during early high tide, it flowed downstream during early low tide, but it stopped flowing at the top of low tide. Because the river bed swelled at river mouth to dam up the river (Fig. 4). When sea level began to raise at the beginning of high tide, sweeping sea water overcame the river bed heap rushing upstream. The river mouth of the Sosobok did not form a saline wedge. The sea water rushed over the fresh river water to form a strong mixing at river mouth. It was concluded that in the study area the soil water salinity was solely supplied by inundation of sea water from the top of the soil.

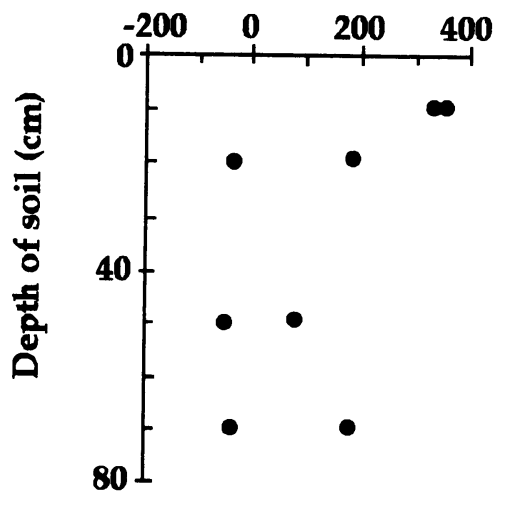

$S$ zone

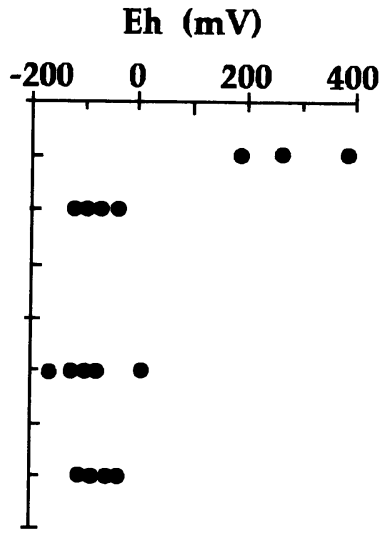

Ra-B zone

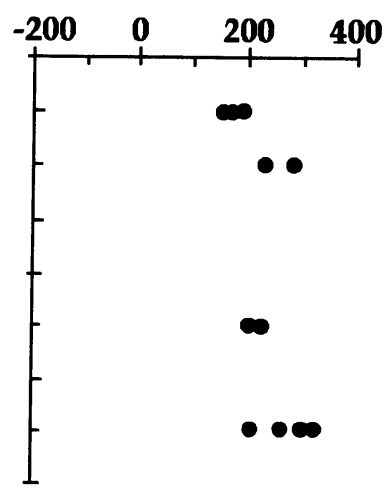

Rs-N zone

Fig. 7. Vertical distribution of redox potential in soil solution . 
$\mathrm{pH}$

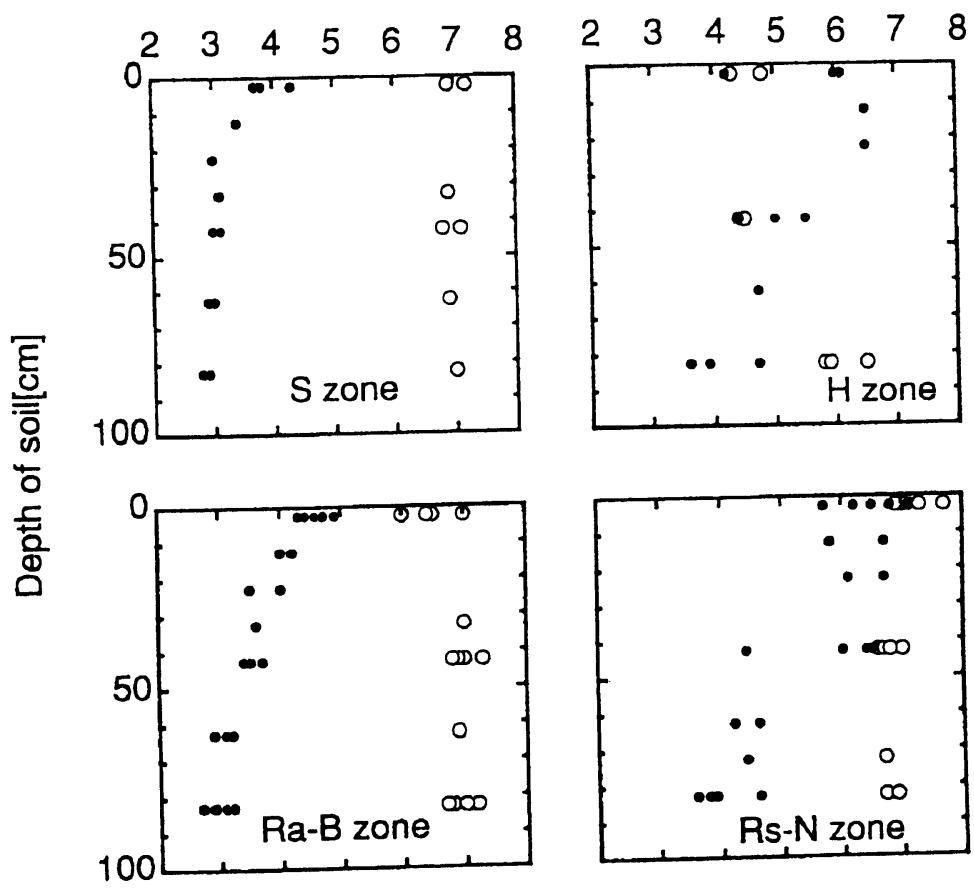

Fig. 8. Vertical distribution of the $\mathrm{pH}$ of fresh and aerial dried soils. Open circle: fresh soil, solid circle: aerial dried soil.

\section{Redox potential of soil water}

The vertical distribution of the redox potential of soil water in the S, Ra-B and Rs-N zones are respectively given in Fig. 7. The redox potentials at top $10 \mathrm{~cm}$ were ubiquitously high, showing aerobic or oxidative condition. But those of the $\mathrm{S}$ and Ra-B zones, sharply declined at $20 \mathrm{~cm}$ to show strongly reductive condition. In the Rs-N zone where soil water was mobile, the redox potential remained comparatively high until $70 \mathrm{~cm}$ depth. The condition here was oxidative to slightly reductive through out.

The zones where the reductive condition observed from shallow layers were corresponded to the zones where the soil water level kept close to ground surface. The soil water level was kept close to ground surface by frequent flood in the $S$ zone and by small water mobility in the Ra-B zone. Both of the inundation frequency and water mobility of the soil could result the reductive and/or anaerobic condition of the soil.

\section{pH of soil}

The results of $\mathrm{pH}$ measurements performed on the fresh and dried soils were illustrated in Fig. 8. The $\mathrm{pH}$ of fresh soil revealed to keep rather constant values at ca. 7 from the ground surface to the deeper subsoil. Slightly fluctuated toward 6 at the top of the Ra-B zone. Only the exception is the $\mathrm{H}$ zone. Upper layer of the $\mathrm{H}$ zone tended to show lower $\mathrm{pH}$ than the others. But the deeper the soil , the higher the $\mathrm{pH}$ became. The fresh soil seemed to remain neutral ubiquitously.

The $\mathrm{pH}$ of dried soil varied remarkably by zones and depths. The top $10 \mathrm{~cm}$ of the $\mathrm{S}$ zone 
showed $\mathrm{pH}$ range of 3.5 and $4,20 \mathrm{~cm}$ and below at 3 and less. Similar patterns were observed in the Ra-B and Rs-N zones. The pH of top soil up to $40 \mathrm{~cm}$ in the Rs-N zone, however, remained between 6 and 7 even when dried. In the $\mathrm{H}$ zone the deeper the soil, the lower the $\mathrm{pH}$ to turn acidic but less remarkably.

It was revealed the soils under highly reductive condition were susceptible to show strong acidity when dried. We did not examine the amount of sulfide in the sample soils. However, the results of $\mathrm{pH}$ measurement suggested that sulfide were accumulated in the soils under reductive condition. The latent acid sulfate soils were formed by soil-water regime, frequent flooding and/or low soil water mobility.

\section{DISCUSSION}

The inundation frequency and the length of no inundation period used to be discussed in relation to the salinity gradient. Chapman (1976) noted that the most important aspect of tidal phenomenon is the length of no inundation period which related to salt accumulation by evaporation. The results of present study showed that the inundation frequency and length of no inundation period also affected to such other factors as redox potential and $\mathrm{pH}$ of soil.

Frequency and period of inundation were determined by the tidal range and the ground surface elevation. If the elevation was between neap high tide and spring high tide no inundation period during neap tide prolonged and if it was lower than neap high tide inundation occurred everyday. Since the water mobility through the soil was very slow, the soil water level was kept close to ground surface on flooded days. At the area higher than neap high tide, soil water level decreased deeper during the neap period. Soil water level in such area fluctuated periodically to follow spring tidal cycle. The cyclic movement induced by spring tidal cycle was reported from salt marshes (Chapman, 1938). He discussed that soil resistance to water permeability caused the cyclic movement. We can conclude that combination of low water mobility and spring tidal cycle resulted to the pattern of soil water movement.

The depth of soil water stagnant is closely related to redox potential of soil water. If soil water level fluctuated periodically, soil redox potential seemed to fluctuate. In the present study, we could not detect such periodical changes of redox potential. The periodical change

Table 3. The number of flooding high tides per month for each measuring points.

\begin{tabular}{lrrrrrrrrrrrr}
\hline Point & \multicolumn{10}{c}{ Number of flooding high tides per month } \\
\cline { 2 - 14 } No. & Jan. & Feb. & Mar. & Apr. May & Jun. & Jul. Aug. & Sep. & Oct. & Nov. Dec. \\
\hline 1 & 60 & 54 & 59 & 58 & 60 & 58 & 60 & 60 & 58 & 60 & 58 & 60 \\
2 & 55 & 45 & 52 & 54 & 60 & 58 & 60 & 60 & 58 & 60 & 58 & 58 \\
3 & 56 & 49 & 53 & 57 & 60 & 58 & 60 & 60 & 58 & 60 & 58 & 60 \\
4 & 0 & 0 & 0 & 0 & 0 & 0 & 0 & 0 & 0 & 0 & 0 & 0 \\
5 & 8 & 11 & 16 & 16 & 18 & 23 & 36 & 38 & 37 & 34 & 20 & 11 \\
6 & 9 & 15 & 20 & 21 & 21 & 25 & 38 & 40 & 40 & 37 & 24 & 14 \\
7 & 17 & 22 & 27 & 26 & 30 & 37 & 46 & 45 & 43 & 41 & 32 & 22 \\
8 & 60 & 54 & 59 & 58 & 60 & 58 & 60 & 60 & 58 & 60 & 58 & 60 \\
9 & 7 & 9 & 12 & 13 & 16 & 20 & 32 & 36 & 34 & 33 & 19 & 11 \\
10 & 19 & 22 & 29 & 28 & 30 & 38 & 47 & 47 & 44 & 42 & 33 & 24 \\
\hline$*$
\end{tabular}

*: according to a tide table (Maritime Safety Agency Japan, 1985) 
of redox potential, related to spring tidal cycle, were reported from the salt marsh soil (Armstrong et al., 1985).

Diemont and Wijngaarden(1974) reported that even if the inundation frequency was the same, the depth of oxidized top soil could be changeable. They considered it because of soil drainage condition were different from site to site. In the present study, we examined the redox potential. The Ra-B and Rs-N zones, where the inundation frequency was the same and soil water mobility was different, the depth of oxidative soil water collected was different.

As tidal movement induced by lunar gravity, the tide height fluctuate periodically in a year. Table 3 shows the number of high tides exceed the ground level per month for each measuring points. The figures of the $\mathrm{S}$ and $\mathrm{H}$ zone do not change throughout the year. On the contrary, those of the Ra-B and Rs-N zones change month to month. In September, when field survey was conducted, it was the season of the higher tide. For the months of lower high tide, no inundation period of the Ra-B and Rs- $\mathrm{N}$ zones are to be expected. The longest no inundation period observed for point Nos. 5 and 9 was 4 days in September and it was estimated 21 days in December.

When the no inundation period prolonged, the water level lowered. The soil water was desiccated and soil became dried. The soil pores were air-filled and the oxygen could reach the deep subsoil. Soil condition turned to oxidative. The depth of oxidative layers of soil in Ra-B and Rs-N zones in December are deeper than those observed in September. The changes from neutral to acidic reaction of soil occurs with the change of reductive condition to oxidative. The $\mathrm{pH}$ of surface soils of Ra-B zone seemed to decrease in such period and return to neutral in the seasons of the higher tide. The reversible process took place cyclic in accordance with the process of soil-water regime.

The $\mathrm{pH}$ changes have been reported occurring cyclic naturally. In a northern Australian mangrove forest, during the periods of the maximum $\mathrm{Eh}$, the $\mathrm{pH}$ was consistently low at 6.2 to 6.6 and during other periods the $\mathrm{pH}$ was less variable at around 6.8 to 7.0 (Boto and Wellington, 1984). In Mozambique, during periods of neap tide the water $\mathrm{pH}$ in creeks and pools fell to 7.6, but when the mangrove was flooded during spring tide it returned to 8.4 the normal value of the open beach (Macnae and Kark, 1962). The $\mathrm{pH}$ value reported seemed to fluctuate but not to the range of strong acidity.

Highly acidic condition, less than $\mathrm{pH} 4$, has been observed in a natural forest stand in Malay peninsula by Diemont and Wijngaarden(1974). But it was restricted only on the top of mud lobster mounds. From the examinations of the mangrove soils in Sierra Leone, it was concluded when the soils of reclaimed land area drained in the following dry season, intense acidity appeared. The pH value fell from between 6 and 7 to below 3 (Jordan, 1964).

From our field study in Halmahera Is. and works done by various authors, it was concluded a natural process in a mangrove soil-water relationship maintains a certain level of oxidation-reduction conditions, soil reaction and salinity. It is an ecosystem homeostasis. But once the ecosystem is heavily exploited due to such human disturbances as clear cut for timbers, land reclamation for agriculture, fish pond, coastal development and so on, on large scale introduced, the natural dynamic equilibrium is undoubtedly destroyed, and the recovery by natural process may not be possible.

ACKNOWLEDGEMENTS We are grateful to Dr. K. Komiyama (Gifu University), Mr. H. Moriya (Kagawa University), Mr. Suhardjono (Herbarium Bogorience) and Dr. A. 
Budiman (Balitbang Zoologi, LBN) for their cooperation in field works. Our hearty thank are also extended to Mr. B. Wattimena and Mr. R. da Costa (LON Ambon) for their help in the field. The Indonesian institute of sciences, LBN, LON, LON Ambon, was good enough to issue us research permission to the project on "Species Biological Studies of Mangrove Ecosystem in East Indonesia". We wish to thank Dr. I. Ninomiya (Ehime University) cooperation in preparing the manuscript. The study was financially supported by Overseas Scientific Research Program No. 61041058 of the Ministry of Education, Science and Culture, Japan.

\section{REFERENCES}

Armstrong, W., Wright, E. J., Lythe, S. \& Gaynard, T. J. 1985. Plant zonation and the effects of the spring-neap tidal cycle on soil aeration in a Humber salt marsh. Journal of Ecology 73: 323-329.

Boerema, J. 1925. Rainfall in the Netherlands Indies. Landsdrukkerij, Weltevreden. 192 pp.

Boto, K. G. \& Wellington, J. T. 1984. Soil characteristics and nutrient status in a Northern Australian mangrove forest. Estuaries 7: 61-69.

Chapman, V. J. 1938. Studies in salt marsh ecology, sections I to III. Journal of Ecology 26:144-179.

_ 1976. Mangrove vegetation. Cramer, Lehre. $447 \mathrm{pp}$.

Clarke, L. D. \& Hannon, N. J. 1969. The mangrove swamp and salt marsh communities of the Sydney district II. The holocoenotic complex with particular reference to physiography. Journal of Ecology 57:213-234.

Clough, B. F. 1983. Mangroves and sewage: a re-evaluation. In Teas, H. J. (ed.): Tasks for Vegetation Science, 8: 151-161, Dr W. Junk Publishers, The Hague.

Diemont, W. H. \& Wijngaarden, W. 1975. Sedimentation patterns, soils, mangrove vegetation and land use in tidal areas of West Malaysia. Proceedings of International Symposium on Biology and Management of Mangroves 2:513527.

Jordan, H. J. 1964. The relation of vegetation and soil to development of mangrove swamps for rice growing in Sierra Leone. Journal of Applied Ecology 1: 209-212.

Komiyama, A., Moriya, H., Prawiroatomojo, S., Toma T. \& Ogino K.1988a. Floristic composition and stand structure. In: Ogino, K. \& Chihara, M. (ed.), Biological System of Mangroves, 85-96. Ehime University, Matsuyama.

$-\longrightarrow,-\frac{1}{-}-1988 \mathrm{~b}$. Primary productivity of mangrove forest. In: Ogino, K. \& Chihara, M. (ed.), Biological System of Mangroves, 97-117. Ehime University, Matsuyama.

Kyuma, K. 1986. Lowland swamp soils in South East Asia. In: Tropical Agriculture Research Center (ed.), Lowl and Swamp in South East Asia, 41-103. Nourin-Tokei Kyoukai, Tokyo (in Japanese).

Macnae, W. 1968. A general account of the fauna and flora of mangrove swamps and forests in the Indo-West-Pacific region. Advances in Marine Biology 6: 73-270.

— Kark, M. 1962. The ecology of mangrove swamps at Inhaca Island, Mozambique. Journal of Ecology 50: 93-128.

Maritime Safety Agency Japan. 1985. 1986 Tide Tables, vol. 2, Pacific and Indian oceans. Nihon Suiro Kyoukai, Tokyo. 291 pp. (in Japanese). 
Russsel, E. W. 1973. Soil Condition and Plant Growth (10th ed.) Longmans. 991 pp.

Spenceley, A. P. 1983. Aspects of the development of mangals in the Townsville Region, North Queensland, Australia. In: Teas, H. J. (ed.): Tasks for Vegetation Science, 8: 151161. Dr. W. Junk Publishers, The Hague.

Watson, J. G. 1928. Mangrove forests of the Malay Peninsula. Malayan Forest Records, 6, $275 \mathrm{pp}$.

Received Sept. 25, 1994

Accepted Oct. 20, 1995

\section{藤間 剛, 荻野和彦＼cjkstart東インドネシア、ハルマヘラ島のマングローブ林の土䁃水位変動}

マングローブ林は沿岸域に成立する森林である。マングローブ林の土は, 多かれ少なかれ海水の 影響をうけるから，高い塩分濃度をとることがある。水が停滞すると極端な低酸素状態に陥り， 嫌気条件下で海水起源の硫化物が集積される。嫌気的条件が好気的条件に変化すると, 集積して いた硫化物が酸化されてつよい酸性をしめすことがある。潮汐変化に対する土畩中で水の移動, 土壤水位と土壤の酸化還元状態および $\mathrm{pH}$ の関係について調べた。

調查地は, 東インドネシア, ハルマヘラ島カオのソソボック川河口部にあるよく発達したマン グローブ林である。植生帯は海側より順に, 河口部の Sonneratia alba 優占林 (Sゾーン), 海岸 線を形成する幅の狭い砂丘上の Hibiscus tiliaceus 優占林 (Hゾーン), 砂丘後部の泥地上の Rhizophora apiculata, Bruguiera gymnorrhiza 混交林（Ra-B ゾーン）および Rhizophora stylosa, Nypa fruticans, Xylocarpus granatum が優占する林分（Rs-Nゾーン）に区分できた。

冠水の頻度と継続時間は, 潮位と地盤高との関係で定まっていた。小潮満潮で冠水する Sゾー ンは, 冠水頻度が高く 1 回の冠水時間が長かった。大潮満潮で冠水する Ra-B ゾーンおよび Rs-N ゾーンでは, 冠水頻度が低く冠水時間も短かった。また小潮前後には数日間にわたって非冠水時 間が継続した。Hゾーンは大潮満潮よりも高いため冠水しなかった。地表が冠水すると土壤水位 は地表面まで上昇した。Hゾーンと川岸のごく近くをのぞけば，冠水しないとき土壌水位は低下 する一方であったが, 低下速度が遅いため, 冠水日には土壤水位は地表面近くに保たれていた。 Ra-B ゾーンと Rs-N ゾーンでは, 小潮の前後には非冠水時間が数日におよび, 冠水日よりも土 壤水位の低下幅が大きくなった。しかし, Rs-Nゾーンの土壤水位が地表から $70 \mathrm{~cm}$ の深さまで 低下するのに対して, Ra-Bゾーンのそれは $30 \mathrm{~cm}$ にとどまった。そのため土壌中の水の移動性 は, Ra-Bゾーンで小さくRs-Nゾーンで大きいと考えることができた。

土壤水位の低下幅の小さい Sゾーンと Ra-B ゾーンの土㙞水は, 深さ $20 \mathrm{~cm}$ から強い還元状態 をしめした。それに対して土壤水位の低下幅が大きいRs-N ゾーンの土壇水は深さ $70 \mathrm{~cm}$ でも, 弱い還元状態をしめすのみであった。SゾーンとRa-Bゾーンの土は, 表層のものから風乾による $\mathrm{pH}$ の低下が顕著で強い酸性を呈しするようになる。Rs-N ゾーンの土で風乾により強酸性とな るのは下層のものに限られた。冠水頻度および非冠水時間の長さは土壤の塩分濃度に影響するも のとされてきたが, 酸化還元状態と $\mathrm{pH}$ にも影響をおよほしており, 土壤中での水の移動性の違 いにより，そのあらわれかたが変化することが明らかになった。また潮位の季節的変化が大きい 場合は, 冠水頻度が季節により变化し, 酸化還元状態および $\mathrm{pH}$ も周期的に変化すると考察し た。 